\title{
Management of Chronic Obstructive Pulmonary Disease Patients after Hospitalization for Acute Exacerbation
}

\author{
Mirjam Osthoff Jörg D. Leuppi \\ Department of Internal Medicine, University Hospital Basel, Basel, Switzerland
}

\section{Key Words}

Chronic obstructive pulmonary disease, exacerbation •

Pulmonary rehabilitation, early · Oxygen therapy,

long-term $\cdot$ Noninvasive ventilation

\begin{abstract}
The objective of this review is to sum up the literature regarding the management of patients with chronic obstructive pulmonary disease (COPD) after hospitalization for an acute exacerbation. Guidelines recommend a follow-up 4-6 weeks after hospitalization to assess coping strategies, inhaler technique, the need for long-term oxygen therapy and the measurement of $\mathrm{FEV}_{1}$. This review discusses the followup of patients with exacerbations of COPD, the use and value of spirometry in their further management, the potential benefit of home monitoring, the value of long-term oxygen therapy, the value of self-management programs including the use of action plans, the potential benefit of noninvasive ventilation as well as the value of early rehabilitation. There is not enough literature to allow specific recommendations and to define components of a care plan after hospitalization for an acute exacerbation; however, early rehabilitation should be included.

Copyright $\odot 2009$ S. Karger AG, Basel
\end{abstract}

\section{Background}

Acute exacerbations of chronic obstructive pulmonary disease (COPD) are a frequent cause of emergency department visits and hospitalizations. In the United States there was an average of 0.6 million emergency department visits per year for acute exacerbations from 1993 to 2005 [1] resulting in more than 500,000 hospitalizations per year [2].

An exacerbation of COPD is defined by the Global Initiative for Chronic Obstructive Lung Disease (GOLD) as a change in the patient's 'baseline dyspnea, cough, and/or sputum that is beyond day-to-day variations, is acute in onset, and may warrant a change in regular medication' [3]. The management in emergency departments of patients experiencing an acute exacerbation varies despite guideline-recommended care [1]. There is even more uncertainty regarding the management of COPD patients in primary care $[4,5]$. Several risk factors for relapse after acute exacerbations have been identified. These include the number of previous exacerbations, the use of home oxygen, low lung function, $\mathrm{FEV}_{1}<35 \%$, the absence of a primary caregiver and the choice of oral therapy [6-16]. The question remains: how should a patient with COPD be managed after hospitalization or emergency department visit for an acute exacerbation? 


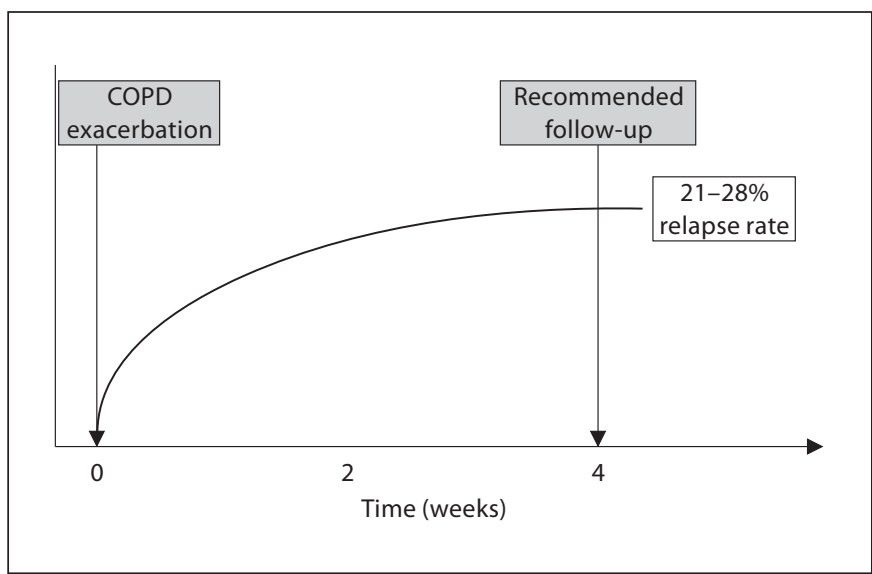

Fig. 1. Recommended follow-up in relation to relapse rate.

The objective of this study was to review the literature regarding the follow-up of patients with exacerbations, the use and value of spirometry in their further management, the potential benefit of home monitoring, the value of long-term oxygen therapy, the value of self-management programs including the use of action plans, the potential benefit of noninvasive ventilation as well as the value of early rehabilitation.

\section{Follow-Up}

The COPD guidelines published by GOLD recommend a follow-up visit 4-6 weeks after hospitalization for COPD including an assessment of the patient's ability to cope in his usual environment, a reassessment of inhaler technique, measurement of $\mathrm{FEV}_{1}$ and an assessment of the need for long-term oxygen therapy [3].

Up to one third of the patients presenting at the emergency department with an acute exacerbation are newly diagnosed with COPD [17]. After an emergency department visit for an exacerbation of COPD there is a $21-28 \%$ relapse rate during the first 2 weeks after discharge [13, 18]. In the study conducted by Murata et al. [13] the relapse rate leveled off within the first 14 days after discharge. Patients with asthma were also included in this study while patients with an exacerbation requiring hospitalization were excluded [13]. In the prospective multicenter study by Kim et al. [18] only patients with acute exacerbations of COPD were included. Patients requiring hospitalization were also excluded. Patients who showed a high risk of relapse needing urgent attention had a his- tory of prior emergency care utilization [18]. Patients who frequently use emergency care services more often lack a primary caregiver than those who use emergency services less frequently [15]. On the other hand, in a different study, COPD patients with intensified access to primary care showed a trend toward higher readmission rates than the control group, although the study was not powered for subgroup analysis according to disease categories [19].

In other studies, relapse was defined as an event occurring within a maximum period of 4 weeks $[7,9,20$, 21].

It has also been shown that exacerbations are not random events but that the risk of recurrence is greatest within the 8 weeks following the initial event [22]. If, as recommended by the GOLD guidelines, a patient is seen for follow-up 4-6 weeks after an exacerbation, the primary caregiver misses out on more than $20 \%$ of the relapses which occur within this time period (fig. 1). The question remains whether a follow-up earlier after discharge could reduce the high relapse (or re-exacerbation) rate.

In the study by Casas et al. [23] patients were recruited after hospitalization for an acute exacerbation of COPD and either assigned to standard care or to an integrated care intervention. Patients in the integrated care group were thoroughly assessed at discharge in terms of their respiratory disease, comorbidities and their social support. These patients were also educated on self-management and they had access to a specialized nurse via call center. No regular follow-up was scheduled. The aforementioned measures reduced the rehospitalization rate for the period of 1 year but had no influence on mortality [23].

Hermiz et al. [24] conducted a study, randomizing patients after hospitalization for an acute exacerbation to a control group receiving standard care and an intervention group. Patients in the intervention group were visited by a nurse within 1 week after discharge, were educated on disease management and received a care plan. This intervention did not reduce the number of emergency department visits or hospital admissions [24]. Table 1 sums up the characteristics of the mentioned studies.

To the best of our knowledge there is no study comparing the relapse rate of COPD patients after hospitalization for an acute exacerbation with differences in timing or frequency of follow-up visits as the sole intervention. 
Table 1. Overview of studies regarding relapse after COPD exacerbation

\begin{tabular}{|c|c|c|c|c|c|}
\hline Study & $\begin{array}{l}\text { Characteristics of } \\
\text { patients included }\end{array}$ & $\begin{array}{l}\text { Number of patients/ED } \\
\text { visits or hospitalizations }\end{array}$ & $\begin{array}{l}\text { Length of } \\
\text { follow-up }\end{array}$ & Relapse rate & Definition of relapse \\
\hline $\begin{array}{l}\text { Murata } \\
\text { et al. [14] }\end{array}$ & $\begin{array}{l}\text { Patients visiting ED for } \\
\text { exacerbation }\end{array}$ & 496/868 ED visits & 14 days & $28.1 \%$ & $\begin{array}{l}\text { Unscheduled visit to ED for } \\
\text { respiratory symptoms }\end{array}$ \\
\hline $\begin{array}{l}\text { Kim } \\
\text { et al. [18] }\end{array}$ & $\begin{array}{l}\text { Patients visiting ED for } \\
\text { exacerbation }\end{array}$ & 151/151 ED visits & 14 days & $21 \%$ & $\begin{array}{l}\text { Unscheduled visit to physician for } \\
\text { worsening of COPD symptoms }\end{array}$ \\
\hline $\begin{array}{l}\text { Tsai } \\
\text { et al. [15] }\end{array}$ & $\begin{array}{l}\text { Patients visiting ED for } \\
\text { worsening of COPD symptoms }\end{array}$ & 388/1,009 ED visits & 1 year & $21 \%$ in 14 days & $\begin{array}{l}\text { Unscheduled visit to ED for } \\
\text { worsening of COPD symptoms }\end{array}$ \\
\hline $\begin{array}{l}\text { Weinberger } \\
\text { et al. [19] }\end{array}$ & $\begin{array}{l}\text { Patients hospitalized with } \\
\text { congestive heart failure, } \\
\text { diabetes mellitus, COPD }\end{array}$ & $\begin{array}{l}583 \text { with COPD/ } \\
583 \text { hospitalizations }\end{array}$ & 6 months & $\begin{array}{l}\text { Not powered for } \\
\text { subgroup of COPD } \\
\text { patients }\end{array}$ & Readmission \\
\hline $\begin{array}{l}\text { Adams } \\
\text { et al. [7] }\end{array}$ & $\begin{array}{l}\text { ED visits for COPD } \\
\text { exacerbation }\end{array}$ & 172/362 ED visits & 14 days & $22 \%$ & $\begin{array}{l}\text { Return visit to ED with persistent } \\
\text { or worsening symptoms }\end{array}$ \\
\hline $\begin{array}{l}\text { Dewan } \\
\text { et al. [9] }\end{array}$ & $\begin{array}{l}\text { Outpatients with COPD } \\
\text { exacerbation }\end{array}$ & 228/232 exacerbations & $\begin{array}{l}4 \text { weeks (failure to } \\
\text { respond) } / 24 \text { months }\end{array}$ & $\begin{array}{l}14.7 \% \text { failure- } \\
\text { to-respond rate }\end{array}$ & $\begin{array}{l}\text { Persistence or worsening of COPD } \\
\text { symptoms }\end{array}$ \\
\hline $\begin{array}{l}\text { Aaron } \\
\text { et al. [20] }\end{array}$ & $\begin{array}{l}\text { Patients visiting ED for COPD } \\
\text { exacerbation }\end{array}$ & 147/147 exacerbations & 30 days & $27 \%$ & $\begin{array}{l}\text { Unscheduled visit to physician's } \\
\text { office or ED because of worsening } \\
\text { COPD symptoms }\end{array}$ \\
\hline $\begin{array}{l}\text { Niewoehner } \\
\text { et al. [21] }\end{array}$ & $\begin{array}{l}\text { Patients hospitalized for COPD } \\
\text { exacerbation }\end{array}$ & 271 & 6 months & $\begin{array}{l}30 \text {-day treatment } \\
\text { failure rate of } 27 \%\end{array}$ & $\begin{array}{l}\text { Treatment failure (readmission, } \\
\text { death, intubation) }\end{array}$ \\
\hline $\begin{array}{l}\text { Casas } \\
\text { et al. [23] }\end{array}$ & $\begin{array}{l}\text { Patients hospitalized for COPD } \\
\text { exacerbation }\end{array}$ & $155 / 155$ hospitalizations & 12 months & $\begin{array}{l}31 \text { vs. } 49 \% \\
\text { readmission rate }\end{array}$ & Readmission \\
\hline $\begin{array}{l}\text { Hermiz } \\
\text { et al. [24] }\end{array}$ & $\begin{array}{l}\text { Patients hospitalized for COPD } \\
\text { exacerbation }\end{array}$ & $177 / 177$ hospitalizations & 3 months & $\begin{array}{l}24 \text { vs. } 18 \% \\
\text { hospitalization }\end{array}$ & $\begin{array}{l}\text { Frequency of patients' } \\
\text { presentation and admission to } \\
\text { hospital }\end{array}$ \\
\hline
\end{tabular}

$\mathrm{ED}=$ Emergency department

\section{Spirometry}

The GOLD guidelines recommend spirometry with measurement of $\mathrm{FEV}_{1}$ 4-6 weeks after hospitalization for an acute exacerbation of COPD [3].

In patients with moderate to severe COPD a low level of lung function has been shown to be an independent risk factor for exacerbation and hospitalization. In the study by Niewoehner et al. [25] the percentage of predicted $\mathrm{FEV}_{1}$ was predictive of exacerbations and hospitalization within a 6-month period [25]. However, the use of spirometry for monitoring disease or modifying therapy according to spirometric results has not yet been evaluated in randomized controlled trials [26].

The spirometry results obtained 4-6 weeks after an acute exacerbation might help to identify patients who are at higher risk of relapse or rehospitalization, but there are no data regarding the benefit of therapeutic interventions based upon these results.

COPD Patients after Hospitalization for Acute Exacerbation

\section{Self-Management and the Use of Action Plans}

A variety of studies have evaluated the benefits of patient education and the use of action plans in the management of patients with COPD. The study designs vary greatly regarding the choice of intervention and followup times.

For their study Bourbeau et al. [27] recruited patients who had been hospitalized for an acute exacerbation during the previous year. Patients were only included if the time period between exacerbation and inclusion was at least 4 weeks. The interventions included patient education, an individualized action plan and exercise. The hospital admission rate for exacerbations and the emergency department visits were significantly reduced in the intervention group within the 12-month follow-up period [27]. In the study by Coultas et al. [28] patients received education in the form of problem-based learning and an individually tailored action plan. These measures did not result in fewer hospitalizations or emergency department 
visits within a 6-month follow-up period [28]. No change in the hospitalization rate within 1 year of follow-up was seen in stable COPD patients selected by general practitioners who were assigned to a care plan [29]. In contrast to the first-mentioned study by Bourbeau et al. [27], the studies by Coultas et al. [28] and Martin et al. [29] did not include any form of exercise in the intervention groups. However, a study by Monninkhof et al. [30], for which patients from an outpatient pulmonary clinic were recruited and randomized to a self-management intervention group that included education and a fitness program or to a control group, failed to show a positive effect on the number of exacerbations in the intervention group. The number of hospitalizations or emergency department visits was not reported. In the study by Rea et al. [31], stable COPD patients were recruited and the intervention group was assigned a care plan, action plan, regular check-ups and pulmonary rehabilitation. These patients showed a lower hospital admission rate compared to their pretrial rate. However, when compared to the control group, the hospital admission rate did not decrease significantly [31].

Owing to the great heterogeneity of interventions and different follow-up periods, it is difficult to make specific recommendations. Self-management interventions for patients with COPD that focus on educating them on the disease and the skills needed to guide their health behavior might be associated with a reduction in hospital admissions, but there is insufficient information to specify detailed measures [32]. Data on self-management interventions directly following hospitalizations for an acute exacerbation of COPD, not including rehabilitative programs, are lacking.

The review of action plans in the management of COPD in the Cochrane Database includes 3 studies and concludes that the use of action plans shows no effect on health care utilization but does have a positive effect on the self-initiation of antibiotics and/or oral steroids [33]. The studies included in the Cochrane review are based on stable COPD patients recruited either from outpatient clinics or from general practitioner surgeries [33-35]. There is no literature regarding the use of action plans directly following hospitalization for an exacerbation of COPD and its potential benefit in reducing readmission or relapse, especially its effect on the high acute relapse rates.

\section{Use of Home Monitoring}

Few studies have evaluated the benefits of home monitoring in patients with COPD and its effect on relapse rates, quality of life and health care costs. Vitacca et al. [36] conducted a telemedicine study in patients needing mechanical ventilation or long-term oxygen therapy. Patients randomized to the intervention group received a pulse oximetry device and had scheduled telemonitoring appointments as the main measures. In patients with COPD a reduction in the hospitalization rate was shown within a 1-year follow-up period [36]. In the study by Casas et al. [23] patients discharged after an acute exacerbation were randomized to usual care or an intervention group that included self-management strategies, a care plan and scheduled telemedicine contacts with a specialized nurse. Patients in the intervention group were less likely to be hospitalized within a 1-year follow-up period [23]. There is no information available regarding patients being discharged after an acute exacerbation and the value of different forms of home monitoring, e.g. symptom diary, pulse oximetry measurements or frequent peak flow measurements.

\section{Long-Term Oxygen Therapy}

Clinical guidelines recommend an assessment of the need for long-time oxygen therapy 4-6 weeks after an exacerbation [3], as studies have shown a survival benefit for severely hypoxemic patients with COPD $[37,38]$ and a reduction in the number of hospitalizations [39]. If a patient is medically unstable at the time of oxygen therapy initiation, a reevaluation is recommended 1-3 months later [40]. As most patients start their domiciliary oxygen therapy immediately after hospitalization [39], the recommended reevaluation could be included in the aforementioned follow-up 4-6 weeks after an exacerbation, provided that medical stability has been achieved. Oba et al. [41] concluded in their cross-sectional study that most patients were prescribed long-term oxygen therapy when clinically unstable, and that a significant proportion of these patients remained on this therapy without a reassessment. Close to $60 \%$ of patients who were adequately reevaluated were taken off the oxygen therapy [41]. Normoxemic emphysema patients and COPD patients with only moderate hypoxemia do not benefit from long-term oxygen therapy [42, 43]. Guyatt et al. [44] conducted a randomized trial of strategies for assessing the eligibility for long-term oxygen therapy, in order to restrict this 
Table 2. Noninvasive ventilation in COPD patients

\begin{tabular}{llllll}
\hline Study & Characteristics of patients included & $\begin{array}{l}\text { Number } \\
\text { of patients }\end{array}$ & Intervention & $\begin{array}{l}\text { Follow- } \\
\text { up }\end{array}$ & Outcome \\
\hline $\begin{array}{l}\text { Tuggey } \\
\text { et al. [48] }\end{array}$ & $\begin{array}{l}\text { Patients with recent exacerbation who } \\
\text { tolerated NIV and responded well to it }\end{array}$ & 13 & $\begin{array}{l}\text { Provision of domiciliary NIV } \\
\text { service }\end{array}$ & 1 year & $\begin{array}{l}\text { Reduction in readmissions and hospital } \\
\text { costs }\end{array}$ \\
\hline $\begin{array}{l}\text { Clini } \\
\text { et al. [47] }\end{array}$ & $\begin{array}{l}\text { Patients with stable COPD, } \\
\text { hypercapnic during }>\text { 6 months of LTOT }\end{array}$ & 90 & $\begin{array}{l}\text { Randomization to NIV plus } \\
\text { LTOT vs. LTOT }\end{array}$ & 2 years & $\begin{array}{l}\text { Survival and hospitalization similar, } \\
\text { dyspnea and health-related quality of } \\
\text { life better in NIV group }\end{array}$ \\
\hline $\begin{array}{l}\text { Casanova } \\
\text { et al. [46] }\end{array}$ & Patients with stable severe COPD & 52 & $\begin{array}{l}\text { Randomization to NIV plus } \\
\text { standard care vs. standard care }\end{array}$ & $\begin{array}{l}\text { 1 year } \\
\text { Survival and exacerbations similar, } \\
\text { dyspnea better in NIV group }\end{array}$ \\
\hline
\end{tabular}

NIV $=$ Noninvasive ventilation LTOT $=$ long-term oxygen therapy.

therapy to those who benefit. A reassessment of the patients after 2 months of clinical stability resulted in a significant reduction of patients eligible for oxygen therapy and therefore in a reduction of costs without raising mortality [44]. To assess patients $4-6$ weeks after an exacerbation for their need for long-time oxygen therapy might be too early as clinical stability has not been reached. The value of continuous oxygen therapy commenced immediately after exacerbation and its effect on the early relapse rate has not been studied.

\section{Noninvasive Ventilation}

Patients benefit from positive-pressure ventilation for acute respiratory failure secondary to an exacerbation of COPD [45]. In chronic COPD patients, noninvasive ventilation might result in a reduction of hospitalizations but has not been shown to reduce mortality $[46,47]$. Patients with a recent exacerbation that were offered domiciliary noninvasive ventilation benefited by attaining a reduction in readmissions [48]; however, controlled randomized studies are missing [49]. The results of the studies mentioned are summarized in table 2 . The value of subsequent domiciliary noninvasive ventilation in patients that have recently been hospitalized for an exacerbation and have received noninvasive ventilation during hospitalization has to be elucidated.

\section{Early Rehabilitation}

Rehabilitation that started within a few days of hospital admission for an acute exacerbation has been shown to cause an increase in exercise capacity [50-52]. The hos- pital readmission rate decreased when respiratory rehabilitation was started while the patient was still in hospital for an acute exacerbation, or immediately after discharge, if a supervised exercise program was continued for 6 weeks to 6 months [53-55]. A meta-analysis of randomized controlled trials showed that patients benefit from respiratory rehabilitation after an acute exacerbation of COPD by attaining an improvement in their quality of life and their exercise capacity. A reduction in hospital readmissions and mortality has also been shown [56].

\section{Conclusions}

The COPD guidelines published by GOLD recommend a follow-up visit 4-6 weeks after hospitalization for an acute exacerbation to assess the patients' coping ability, $\mathrm{FEV}_{1}$, inhaler technique, understanding of treatment and their need for long-term oxygen therapy [3]. There is a paucity of literature regarding the follow-up of patients after hospitalization for an acute exacerbation of COPD. Several interventions have been studied to reduce the high relapse rate in these patients. In their systematic review of the chronic care model in COPD management, Adams et al. [57] conclude that patients who received at least 2 chronic-care-model components had lower hospitalization rates, but they also 'highlight the need for welldesigned trials' [57]. Rehabilitation is recommended after an acute exacerbation because it has been shown to reduce the rehospitalization rate and improves exercise capacity and quality of life [56]. However, the availability of rehabilitation poses a problem for many patients in different health care systems. 
Although COPD and its exacerbations are common and present a major financial burden for most health care systems, there is little information on how to manage patients after hospitalization for COPD in order to optimize care and lower the relapse rates. The data cur- rently available do not allow clear recommendations to be made regarding all the components of a care plan, but they strongly indicate that rehabilitation should be included.

\section{References}

1 Tsai CL, Sobrino JA, Camargo CA Jr: National Study of Emergency Department Visits for Acute Exacerbation of Chronic Obstructive Pulmonary Disease, 1993-2005. Acad Emerg Med 2008, E-pub ahead of print.

-2 Mannino DM, Homa DM, Akinbami LJ, Ford ES, Redd SC: Chronic obstructive pulmonary disease surveillance: United States, 1971-2000. MMWR Surveill Summ 2002;51: $1-16$.

3 Global Initiative for Chronic Obstructive Lung Disease (GOLD): COPD guidelines. 2008. http://www.goldcopd.com.

$\checkmark 4$ Yawn BP, Wollan PC: Knowledge and attitudes of family physicians coming to COPD continuing medical education. Int J Chron Obstruct Pulmon Dis 2008;3:311-317.

5 Bourbeau J, Sebaldt RJ, Day A, Bouchard J, Kaplan A, Hernandez P, et al: Practice patterns in the management of chronic obstructive pulmonary disease in primary practice: the CAGE study. Can Respir J 2008;15:1319.

-6 Murata GH, Gorby MS, Kapsner CO, Chick TW, Halperin AK: A multivariate model for the prediction of relapse after outpatient treatment of decompensated chronic obstructive pulmonary disease. Arch Intern Med 1992;152:73-77.

7 Adams SG, Melo J, Luther M, Anzueto A Antibiotics are associated with lower relapse rates in outpatients with acute exacerbations of COPD. Chest 2000;117:1345-1352.

$>8$ Ball P, Harris JM, Lowson D, Tillotson G, Wilson R: Acute infective exacerbations of chronic bronchitis. QJM 1995;88:61-68.

$\checkmark 9$ Dewan NA, Rafique S, Kanwar B, Satpathy H, Ryschon K, Tillotson GS, et al: Acute exacerbation of COPD: factors associated with poor treatment outcome. Chest 2000;117: 662-671.

$\checkmark 10$ Emerman CL, Effron D, Lukens TW: Spirometric criteria for hospital admission of patients with acute exacerbation of COPD. Chest 1991;99:595-599.

-11 McCrory DC, Brown C, Gelfand SE, Bach PB: Management of acute exacerbations of COPD: a summary and appraisal of published evidence. Chest 2001;119:1190-1209.
12 Miravitlles M, Murio C, Guerrero T: Factors associated with relapse after ambulatory treatment of acute exacerbations of chronic bronchitis. DAFNE Study Group. Eur Respir J 2001;17:928-933.

13 Murata GH, Gorby MS, Chick TW, Halperin AK: Use of emergency medical services by patients with decompensated obstructive lung disease. Ann Emerg Med 1989;18:501506.

14 Murata GH, Gorby MS, Chick TW, Halperin AK: Treatment of decompensated chronic obstructive pulmonary disease in the emergency department: correlation between clinical features and prognosis. Ann Emerg Med 1991;20:125-129.

15 Tsai CL, Griswold SK, Clark S, Camargo CA Jr: Factors associated with frequency of emergency department visits for chronic obstructive pulmonary disease exacerbation. J Gen Intern Med 2007;22:799-804.

16 Niewoehner DE: Relation of chronic obstructive pulmonary disease exacerbations to $\mathrm{FEV}_{1}$ : an intricate tango. Respiration 2009;77:229-235.

17 Zoia MC, Corsico AG, Beccaria M, Guarnone R, Cervio G, Testi R, et al: Exacerbations as a starting point of pro-active chronic obstructive pulmonary disease management. Respir Med 2005;99:1568-1575

- 18 Kim S, Emerman CL, Cydulka RK, Rowe $\mathrm{BH}$, Clark S, Camargo CA: Prospective multicenter study of relapse following emergency department treatment of COPD exacerbation. Chest 2004;125:473-481.

19 Weinberger M, Oddone EZ, Henderson WG: Does increased access to primary care reduce hospital readmissions? Veterans Affairs Cooperative Study Group on Primary Care and Hospital Readmission. N Engl J Med 1996;334:1441-1447.

20 Aaron SD, Vandemheen KL, Hebert P, Dales R, Stiell IG, Ahuja J, et al: Outpatient oral prednisone after emergency treatment of chronic obstructive pulmonary disease. $\mathrm{N}$ Engl J Med 2003;348:2618-2625.

21 Niewoehner DE, Erbland ML, Deupree RH, Collins D, Gross NJ, Light RW, et al: Effect of systemic glucocorticoids on exacerbations of chronic obstructive pulmonary disease. Department of Veterans Affairs Cooperative Study Group. N Engl J Med 1999;340:19411947.
-22 Hurst JR, Donaldson GC, Quint JK, Goldring JJ, Baghai-Ravary R, Wedzicha JA: Temporal clustering of exacerbations in chronic obstructive pulmonary disease. Am J Respir Crit Care Med 2009;179:369-374.

23 Casas A, Troosters T, Garcia-Aymerich J, Roca J, Hernandez C, Alonso A, et al: Integrated care prevents hospitalisations for exacerbations in COPD patients. Eur Respir J 2006;28:123-130.

24 Hermiz O, Comino E, Marks G, Daffurn K, Wilson S, Harris M: Randomised controlled trial of home based care of patients with chronic obstructive pulmonary disease. BMJ 2002;325:938.

-25 Niewoehner DE, Lokhnygina Y, Rice K, Kuschner WG, Sharafkhaneh A, Sarosi GA, et al: Risk indexes for exacerbations and hospitalizations due to COPD. Chest 2007;131: 20-28.

$>26$ Wilt TJ, Niewoehner D, MacDonald R, Kane RL: Management of stable chronic obstructive pulmonary disease: a systematic review for a clinical practice guideline. Ann Intern Med 2007;147:639-653.

27 Bourbeau J, Julien M, Maltais F, Rouleau M, Beaupré A, Begin R, et al: Reduction of hospital utilization in patients with chronic obstructive pulmonary disease: a disease-specific self-management intervention. Arch Intern Med 2003;163:585-591.

28 Coultas D, Frederick J, Barnett B, Singh G, Wludyka P: A randomized trial of two types of nurse-assisted home care for patients with COPD. Chest 2005;128:2017-2024.

29 Martin IR, McNamara D, Sutherland FR, Tilyard MW, Taylor DR: Care plans for acutely deteriorating COPD: a randomized controlled trial. Chron Respir Dis 2004; 1 : 191-195.

-30 Monninkhof E, van der Valk P, van der Palen J, van Herwaarden C, Zielhuis G: Effects of a comprehensive self-management programme in patients with chronic obstructive pulmonary disease. Eur Respir J 2003;22: 815-820.

31 Rea H, McAuley S, Stewart A, Lamont C, Roseman P, Didsbury P: A chronic disease management programme can reduce days in hospital for patients with chronic obstructive pulmonary disease. Intern Med J 2004; 34:608-614. 
32 Effing T, Monninkhof EM, van der Valk PD, van der Palen J, van Herwaarden CL, Partidge MR, et al: Self-management education for patients with chronic obstructive pulmonary disease. Cochrane Database Syst Rev 2007;4:CD002990.

33 Turnock AC, Walters EH, Walters JA, WoodBaker R: Action plans for chronic obstructive pulmonary disease. Cochrane Database Syst Rev 2005;4:CD005074.

>34 Gallefoss F, Bakke PS, Rsgaard PK: Quality of life assessment after patient education in a randomized controlled study on asthma and chronic obstructive pulmonary disease. Am J Respir Crit Care Med 1999;159:812-817.

-35 Watson PB, Town GI, Holbrook N, Dwan C, Toop LJ, Drennan CJ: Evaluation of a selfmanagement plan for chronic obstructive pulmonary disease. Eur Respir J 1997;10: 1267-1271.

-36 Vitacca M, Bianchi L, Guerra A, Fracchia C, Spanevello A, Balbi B, et al: Tele-assistance in chronic respiratory failure patients: a randomised clinical trial. Eur Respir J 2009;33: 411-418.

37 Continuous or nocturnal oxygen therapy in hypoxemic chronic obstructive lung disease: a clinical trial. Nocturnal Oxygen Therapy Trial Group. Ann Intern Med 1980;93:391398.

38 Long term domiciliary oxygen therapy in chronic hypoxic cor pulmonale complicating chronic bronchitis and emphysema. Report of the Medical Research Council Working Party. Lancet 1981;i:681-686.

-39 Ringbaek TJ, Viskum K, Lange P: Does longterm oxygen therapy reduce hospitalisation in hypoxaemic chronic obstructive pulmonary disease? Eur Respir J 2002;20:38-42.

$\checkmark 40$ Petty TL, Casaburi R: Recommendations of the Fifth Oxygen Consensus Conference. Writing and Organizing Committees. Respir Care 2000;45:957-961.
1 Oba Y, Salzman GA, Willsie SK: Reevaluation of continuous oxygen therapy after initial prescription in patients with chronic obstructive pulmonary disease. Respir Care 2000;45:401-406.

42 Drummond MB, Blackford AL, Benditt JO, Make BJ, Sciurba FC, McCormack MC, et al: Continuous oxygen use in nonhypoxemic emphysema patients identifies a high-risk subset of patients: retrospective analysis of the National Emphysema Treatment Trial. Chest 2008;134:497-506.

43 Gorecka D, Gorzelak K, Sliwinski P, Tobiasz M, Zielinski J: Effect of long-term oxygen therapy on survival in patients with chronic obstructive pulmonary disease with moderate hypoxaemia. Thorax 1997;52:674-679.

44 Guyatt GH, Nonoyama M, Lacchetti C, Goeree R, McKim D, Heels-Ansdell D, et al: A randomized trial of strategies for assessing eligibility for long-term domiciliary oxygen therapy. Am J Respir Crit Care Med 2005; 172:573-580.

45 Ram FS, Picot J, Lightowler J, Wedzicha JA: Non-invasive positive pressure ventilation for treatment of respiratory failure due to exacerbations of chronic obstructive pulmonary disease. Cochrane Database Syst Rev 2004;CD004104.

46 Casanova C, Celli BR, Tost L, Soriano E, Abreu J, Velasco V, et al: Long-term controlled trial of nocturnal nasal positive pressure ventilation in patients with severe COPD. Chest 2000;118:1582-1590.

-47 Clini E, Sturani C, Rossi A, Viaggi S, Corrado $\mathrm{A}$, Donner $\mathrm{CF}$, et al: The Italian multicentre study on noninvasive ventilation in chronic obstructive pulmonary disease patients. Eur Respir J 2002;20:529-538.

48 Tuggey JM, Plant PK, Elliott MW: Domiciliary non-invasive ventilation for recurrent acidotic exacerbations of COPD: an economic analysis. Thorax 2003;58:867-871.

49 Elliott MW: Non-invasive ventilation in acute exacerbations of COPD: what happens after hospital discharge? Thorax 2004;59: 1006-1008.
50 Behnke M, Taube C, Kirsten D, Lehnigk B, Jörres RA, Magnussen H: Home-based exercise is capable of preserving hospital-based improvements in severe chronic obstructive pulmonary disease. Respir Med 2000;94: 1184-1191.

51 Kirsten DK, Taube C, Lehnigk B, Jörres RA, Magnussen $\mathrm{H}$ : Exercise training improves recovery in patients with COPD after an acute exacerbation. Respir Med 1998;92: 1191-1198.

52 Nava S: Rehabilitation of patients admitted to a respiratory intensive care unit. Arch Phys Med Rehabil 1998;79:849-854.

53 Behnke M, Jörres RA, Kirsten D, Magnussen $\mathrm{H}$ : Clinical benefits of a combined hospital and home-based exercise programme over 18 months in patients with severe COPD. Monaldi Arch Chest Dis 2003;59:44-51.

54 Man WD, Polkey MI, Donaldson N, Gray BJ, Moxham J: Community pulmonary rehabilitation after hospitalisation for acute exacerbations of chronic obstructive pulmonary disease: randomised controlled study. BMJ 2004;329:1209.

55 Murphy N, Bell C, Costello RW: Extending a home from hospital care programme for COPD exacerbations to include pulmonary rehabilitation. Respir Med 2005;99:12971302.

56 Puhan MA, Scharplatz M, Troosters T, Steurer J: Respiratory rehabilitation after acute exacerbation of COPD may reduce risk for readmission and mortality: a systematic review. Respir Res 2005;6:54.

57 Adams SG, Smith PK, Allan PF, Anzueto A, Pugh JA, Cornell JE: Systematic review of the chronic care model in chronic obstructive pulmonary disease prevention and management. Arch Intern Med 2007;167:551-561. 